\title{
Biogeochemical controls on the bacterial populations in the eastern Atlantic Ocean
}

\author{
S. B. Neogi ${ }^{1,2}$, B. P. Koch ${ }^{3,4}$, P. Schmitt-Kopplin ${ }^{5}$, C. Pohl ${ }^{6}$, G. Kattner ${ }^{3}$, S. Yamasaki ${ }^{1}$, and R. J. Lara ${ }^{7,8}$ \\ ${ }^{1}$ Graduate School of Life and Environmental Sciences, Osaka Prefecture University, Sakai, Osaka 599-8531, Japan \\ ${ }^{2}$ International Centre for Diarrhoeal Disease Research, Bangladesh, 68 Shaheed Tajuddin Ahmed Sarani, Mohakhali, \\ Dhaka 1212, Bangladesh \\ ${ }^{3}$ Alfred Wegener Institute for Polar and Marine Research, Ecological Chemistry, Am Handelshafen 12 , \\ 27570 Bremerhaven, Germany \\ ${ }^{4}$ University of Applied Sciences, 27568 Bremerhaven, Germany \\ ${ }^{5}$ Research Unit BioGeoChemistry and Analytics, Helmholtz Zentrum München, Ingoldstädter Landstr. 1, \\ 85764 Neuherberg, Germany \\ ${ }^{6}$ Leibniz Institute for Baltic Sea Research, Seestr. 15, 18119 Warnemünde, Germany \\ ${ }^{7}$ Argentine Institute of Oceanography, 8000 Bahía Blanca, Argentina \\ ${ }^{8}$ Leibniz Centre for Tropical Marine Ecology GmbH, Fahrenheitstr. 6, 28359 Bremen, Germany
}

Received: 23 July 2011 - Published in Biogeosciences Discuss.: 4 August 2011

Revised: 29 November 2011 - Accepted: 2 December 2011 - Published: 20 December 2011

\begin{abstract}
Little is known about bacterial dynamics in the oligotrophic ocean, particularly about cultivable bacteria. We examined the abundance of total and cultivable bacteria in relation to changes in biogeochemical conditions in the eastern Atlantic Ocean with special regard to Vibrio spp., a group of bacteria that can cause diseases in human and aquatic organisms. Surface, deep water and plankton $(<20 \mu \mathrm{m}, 20-$ $55 \mu \mathrm{m}$ and $>55 \mu \mathrm{m})$ samples were collected between $50^{\circ} \mathrm{N}$ and $24^{\circ} \mathrm{S}$. Chlorophyll- $a$ was very low $\left(<0.3 \mu \mathrm{g}^{-1}\right)$ in most areas of the nutrient-poor Atlantic, except at a few locations near upwelling regions. In surface water, dissolved organic carbon (DOC) and nitrogen (DON) concentrations were 64$95 \mu \mathrm{MC}$ and $2-10 \mu \mathrm{M} \mathrm{N}$ accounting for $\geq 90 \%$ and $\geq 76 \%$ of total organic $\mathrm{C}$ and $\mathrm{N}$, respectively. DOC and DON gradually decreased to $\sim 45 \mu \mathrm{MC}$ and $<5 \mu \mathrm{MN}$ in the bottom water. In the surface layer, culture independent total bacteria and other prokaryotes represented by 4'-6-diamidino2-phenylindole (DAPI) counts, ranged mostly between $10^{7}$ and $10^{8}$ cells $1^{-1}$, while cultivable bacterial counts (CBC) and Vibrio spp. were found at concentrations of $10^{4}-10^{7}$ and $10^{2}-10^{5}$ colony forming units (CFU) $1^{-1}$, respectively. Most bacteria ( $>99 \%$ ) were found in the nanoplankton fraction $(<20 \mu \mathrm{m})$, however, bacterial abundance did not correlate with suspended particulates (chlorophyll- $a$, particulate
\end{abstract}

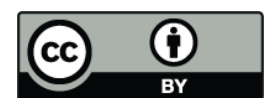

Correspondence to: R. J. Lara (ruben.lara@zmt-bremen.de) organic $\mathrm{C}[\mathrm{POC}]$ and $\mathrm{N}[\mathrm{PON}])$. Instead, we found a highly significant correlation between bacterial abundance and temperature $(p<0.001)$ and a significant correlation with DOC and DON ( $p<0.005$ and $<0.01$, respectively). In comparison to CBC and DAPI-stained prokaryotes, cultivable Vibrio showed a stronger and highly significant correlation with DOC and DON ( $p<0.0005$ and $p<0.005$, respectively). In cold waters of the mesopelagic and abyssal zones, CBC was 50 to 100-times lower than in the surface layer; however, cultivable Vibrio spp. could be isolated from the bathypelagic zone and even near the seafloor (average $\sim 10 \mathrm{CFU}^{-1}$ ). The depth-wise decrease in CBC and Vibrio coincided with the decrease in both DOC and POC. Our study indicates that Vibrio and other bacteria may largely depend on dissolved organic matter to survive in nutrient-poor oceanic habitats.

\section{Introduction}

Oceans play an important role in maintaining the balance of atmospheric $\mathrm{CO}_{2}$. Apart from the conventional biological pump-driven vertical transport of surface organic carbon into the deep sea, the microbial food web remineralizes a large fraction of particulate organic carbon (POC) and ultimately supports primary production (PP) in the euphotic zone (Azam, 1998). Another part is converted into dissolved organic carbon (DOC) supporting prokaryotic production

Published by Copernicus Publications on behalf of the European Geosciences Union. 
(Williams, 2000). The interaction between oceanic bacteria and their energy sources in the water column is a key issue for element fluxes in the ocean. Therefore, detailed information is required about variations in bacterial abundance caused by changes in oceanic biogeochemistry from the surface to abyssopelagic waters.

Marine DOC ( $662 \mathrm{PgC})$ is one of the largest active reservoirs of organic C on Earth (Hansell et al., 2009). Bacteria have a high growth efficiency when using freshly produced, "labile" DOC which can be degraded within several hours to days (Reinthaler and Herndl, 2005). The "semi-labile" DOC (about $15-20 \%$ of net PP) can be degraded by bacteria over weeks to seasonal timescales, while "refractory" DOC are resistant to biodegradation and may bear signatures from centuries to millennia (Hansell et al., 2009). Progressive utilization of labile and semi-labile DOC through the microbial carbon pump aids in the accumulation of refractory DOC ( $\sim 95 \%$ of total DOC) in the oceans interior (Jiao et al., 2010). In a recent study it has been revealed that such transformation processes in the surface ocean are rapidly leading to a relatively fresh component which resembles the refractory material (Flerus et al., 2011). Besides DOC, the availability and nature of nitrogenous components of dissolved organic matter (DOM) play an important role in the biogeochemical cycle by limiting bacterial growth. The concentration of dissolved inorganic nitrogen (DIN) in oceanic surface water is often very low and thus phytoplankton and bacterioplankton are often competing for DIN (Wu et al., 2000). Therefore, recycling of organic nitrogen from particulate (PON) or dissolved (DON) sources may modulate primary production as well as bacterial abundance.

Among the diverse groups of marine and estuarine bacteria, Vibrio species have gained increased attention due to their potential to cause diseases in humans; such as epidemic cholera, which is caused by V. cholerae. Some Vibrio spp. can also cause diseases in economically important fishes and shrimps, and have been identified as a cause of coral bleaching and squid luminescence (Thomson et al., 2004). Vibrio spp. are among the few bacteria that can degrade chitinous substrates, which are among the most abundant amino sugars in the ocean (Thompson et al., 2004). Moreover, this group of bacteria can also secrete a variety of enzymes to aid the degradation of organic matter, e.g., mucinase, protease, lipase, and laminarinase (Oliver et al., 1986; Alderkamp et al., 2007). As part of their strategy for survival in aquatic habitats, Vibrio spp. can attach or interact with virtually all kinds of aquatic organisms or suspended particulates (Lara et al., 2009, 2011). This kind of association of Vibrio and other bacteria is likely facilitated by the release of DOM from plankton or other particulate material.

Until now, microbiological investigations of oceanic habitats have largely focused on culture independent techniques which are basically qualitative, although some studies have applied quantitative fluorescence in situ hybridization (Pernthaler and Amann, 2005). These types of molec- ular analysis have revealed the frequent occurrence of Vibrio spp. in oceanic water, although other subgroups of bacteria, e.g., SAR11, Roseobacter, Alteromonas, and CytophagaFlavobacterium-Bacteroides can also be dominant (Eilers et al., 2000; Malmstrom et al., 2005; Weinbauer et al., 2006; Taniguchi and Hamasaki, 2008; Schattenhofer et al., 2009; Wietz et al., 2010). However, culture independent techniques cannot provide information on the active, cultivable portion of a species. Cultivable bacteria have a highly active metabolism and are the major functional component within a bacterial population; while the remaining viable but noncultivable fraction has a reduced metabolism (Roszak and Colwell, 1987; Sun et al., 2008). Changes in biogeochemical parameters are likely to affect the cultivable fraction more than the non-cultivable part of bacterial community.

Although various ecological studies of Vibrio spp. have been performed in coastal habitats (e.g., Heidelberg et al., 2002; Mahmud et al., 2007, 2008), little is known about the regulation of Vibrio or other bacterial communities in the ocean in response to changes in plankton abundance, temperature and biogeochemical conditions. Among the oceanic bacterial species, Vibrio spp. is of particular interest because of its link with diseases in humans as well as aquatic organisms. Changes in Vibrio populations in the ocean may ultimately affect their coastal populations and consequently human health (Constantin de Magny et al., 2008). In the present study, we examined the quantitative abundance of total and cultivable bacteria including Vibrio spp. at various water depths along a North-South meridional transect through the mostly oligotrophic eastern Atlantic Ocean. Our objectives were to elucidate the importance of particulate and dissolved material for the abundance and distribution of Vibrio spp. and total cultivable and non-cultivable bacteria, and to demonstrate how organic and inorganic substances influence bacterial populations. A better understanding of the abundance and changes in cultivable and total bacterial communities will also improve our knowledge of dynamics and transformation processes of organic carbon and nitrogen in the ocean.

\section{Materials and methods}

\subsection{Study sites and sampling}

Water samples were collected on board R/V Polarstern during the expedition ANT-XXV/1 from Bremerhaven, Germany to Cape Town, South Africa in 2008. The sampling stations covered a variety of geographical areas from $\sim 50^{\circ} \mathrm{N}$ to $\sim 24^{\circ} \mathrm{S}$ including marine waters from the nearby European shelf, the Mediterranean outflow, the inter-tropical convergence zone (ITCZ, between $10^{\circ} \mathrm{N}$ and $2^{\circ} \mathrm{N}$ ), the eastern tropical and sub-tropical Atlantic in the northern and southern hemispheres. The sampling area included stations in the following biogeochemical provinces, as defined by 
Longhurst (2006): North-East Atlantic coastal shelf (NECS), North Atlantic drift region (NADR), North Atlantic subtropical gyre (NASE), North Atlantic tropical gyre (NATR), Eastern tropical Atlantic (ETRA), South Atlantic gyre (SATL) and Benguela current coastal province (BENG).

Surface water (0-10 $\mathrm{m}$ depth) samples were obtained using a Teflon "Fish" sampler, an online device deployed alongside the vessel that continuously pumped water on board. Surface samples were collected at 26 stations from 3 to 29 November 2008 (Fig. 1). In addition, surface water (10001) was fractionated by filtration through plankton nets ( $55 \mu \mathrm{m}$ and $20 \mu \mathrm{m}$ mesh sizes) at nine locations, each covering 50-90 km (Fig. 1). Samples representing the $<20 \mu \mathrm{m}$ fraction were collected during each fractionation by combining filtrates. In addition, water samples from various depths (50-200 m; 1500-2500 $\mathrm{m}$ and 4000-5500 m) were collected at stations 3, 7, 11, 14, 20, 24 and 26 using a CTD rosette sampler $(24 \times 12-1$ bottles) (Fig. 1, Table 1). All samples were transferred into sterile bottles and processed or preserved immediately (within an hour) for microbiological and biogeochemical analyses.

\subsection{Oceanographic variables and chlorophyll measurement}

In situ records of oceanographic variables (water temperature, salinity, depth, etc.) were obtained from the online ship devices. For the chlorophyll- $a$ (Chl- $a$ ) determination, water samples were filtered (GF/F, $47 \mathrm{~mm}$, Whatman) and kept frozen $\left(-80^{\circ} \mathrm{C}\right)$ until extraction with acetone $(90 \%)$ and further analyses of pigments by high performance liquid chromatography (HPLC) and fluorometry according to standard methods (Zapata et al., 2000).

\subsection{Analyses of nutrients and other biogeochemical parameters}

Water samples (3-41) were filtered on board (GF/F, Whatman, precombusted at $450^{\circ} \mathrm{C}, 3 \mathrm{~h}$ ) and afterwards kept frozen at $-20^{\circ} \mathrm{C}$ until analysis for POC and PON. Filtrates $(50 \mathrm{ml})$ were poisoned with $150 \mu \mathrm{l}$ of $\mathrm{HgCl}_{2}\left(35 \mathrm{gl}^{-1}\right)$ and stored at $4{ }^{\circ} \mathrm{C}$ for later nutrient analyses (Kattner, 1999). DIN (nitrate, nitrite, ammonium, all in $\mu \mathrm{M} \mathrm{N})$, silicate $(\mu \mathrm{MSi})$ and phosphate $(\mu \mathrm{MP})$ were determined spectrophotometrically according to standard methods for seawater analysis (Kattner and Becker, 1991). DON was determined by wet oxidation with potassium persulfate (Koroleff, 1983). To determine DOC, water samples were acidified with phosphoric acid $(20 \%, \mathrm{v} / \mathrm{v})$ to remove inorganic C. DOC was measured by high temperature $\left(680^{\circ} \mathrm{C}\right)$ catalytic $\left(\mathrm{Al}_{2} \mathrm{O}_{3}\right.$ particles containing $0.5 \% \mathrm{Pt}$ ) oxidation in a TOC analyzer (Dohrmann DC-190, CA, USA) followed by quantification of $\mathrm{CO}_{2}$ by non-dispersive linearized infrared gas analysis (Skoog et al., 1997). A solution of potassium hydrogen phthalate was used as calibration standard.

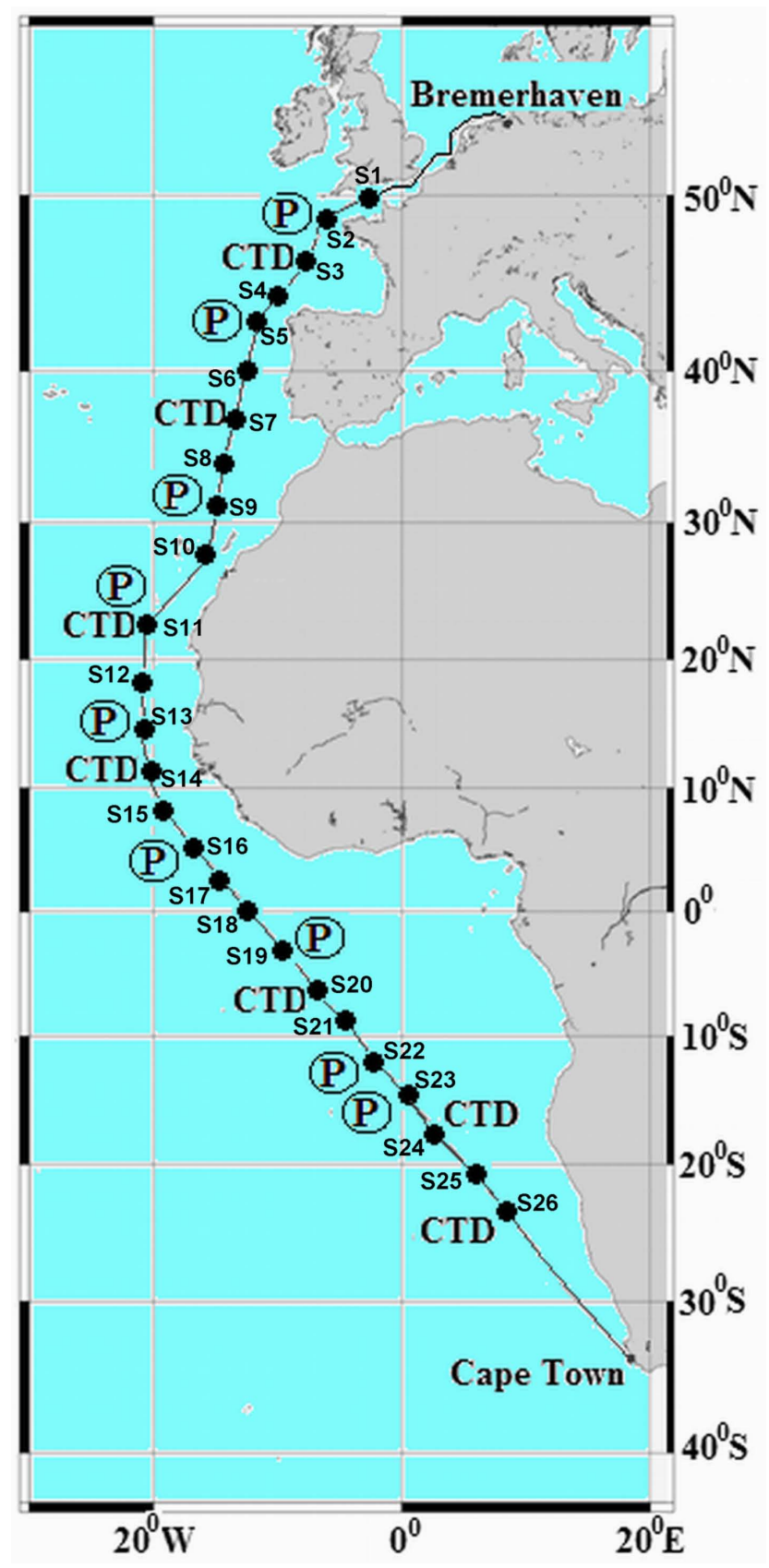

Fig. 1. Sampling stations during the Atlantic Ocean expedition with R/V Polarstern (ANT-XXV/1). Closed circles: stations (S1 to S26) where surface water samples were collected. "P": stations where plankton $(>20 \mu \mathrm{m}$ and $>55 \mu \mathrm{m})$ samples were collected. "CTD": stations where water samples from various depths (50-200 m, 1500-2500 m and 4000-5500 m) were collected.

To determine POC and PON, the preserved filters were dried at $50^{\circ} \mathrm{C}$ for $12 \mathrm{~h}$ and kept at room temperature in a desiccator. For the $\mathrm{POC}$ measurement, inorganic $\mathrm{C}$ was removed by acidification with $\mathrm{HCl}(1 \mathrm{~N})$. POC and PON were quantified with an elemental analyzer (Fisons, NA 2100) according 
Table 1. Average values of nutrients and selected biogeochemical parameters in different surface $(0-10 \mathrm{~m}$ depth $)$ water samples ${ }^{\mathrm{a}}$.

\begin{tabular}{|c|c|c|c|c|c|c|c|c|c|c|c|c|c|c|}
\hline $\begin{array}{l}\text { Stations } \\
\left(\text { samples }^{b}\right)\end{array}$ & $\begin{array}{l}\text { Oceanic } \\
\text { province }^{c}\end{array}$ & Latitude/longitude & Salinity & $\begin{array}{l}\text { Chl- } a \\
\left(\mu \mathrm{gl}^{-1}\right)\end{array}$ & $\begin{array}{l}\text { DOC } \\
(\mu \mathrm{MC})\end{array}$ & $\begin{array}{l}\text { DON } \\
(\mu \mathrm{MN})\end{array}$ & $\begin{array}{l}\mathrm{DIN}^{\dagger} \\
(\mu \mathrm{MN})\end{array}$ & $\begin{array}{l}\mathrm{C} / \mathrm{N} \text { of } \\
\mathrm{DOM}\end{array}$ & $\begin{array}{l}\text { Silicate } \\
(\mu \mathrm{MSi})\end{array}$ & $\begin{array}{l}\text { Phosphate } \\
(\mu \mathrm{MP})\end{array}$ & $\begin{array}{l}\mathrm{N} / \mathrm{P} \\
\text { inorg. }\end{array}$ & $\begin{array}{l}\text { PON } \\
(\mu \mathrm{MN})\end{array}$ & $\begin{array}{l}\text { POC } \\
(\mu \mathrm{MC})\end{array}$ & $\begin{array}{l}\mathrm{Fe} \\
(\mathrm{nM})\end{array}$ \\
\hline $1(\mathrm{~S})$ & NECS & $50.17^{\circ} \mathrm{N} / 2.35^{\circ} \mathrm{W}$ & 35.23 & 0.54 & 69.6 & NM & NM & NM & NM & $\mathrm{NM}$ & NM & 0.74 & 9.3 & NM \\
\hline $2(\mathrm{~S}, \mathrm{P})$ & NADR & $48.53^{\circ} \mathrm{N} / 6.11^{\circ} \mathrm{W}$ & 35.29 & 2.25 & 64.1 & 4.3 & 1.51 & 14.9 & 1.55 & 0.15 & 10.4 & 1.36 & 8.5 & NM \\
\hline $3(\mathrm{~S}, \mathrm{C})$ & & $46.33^{\circ} \mathrm{N} / 7.84^{\circ} \mathrm{W}$ & 35.65 & 0.18 & 65.6 & 2.6 & 1.63 & 25.2 & 1.24 & 0.14 & 11.6 & 1.10 & 8.7 & NM \\
\hline $4(S)$ & NASE & $44.04^{\circ} \mathrm{N} / 10.29^{\circ} \mathrm{W}$ & 35.90 & 0.78 & 66.3 & 4.3 & 0.68 & 15.4 & 0.81 & 0.10 & 7.2 & 1.04 & 6.7 & 1.20 \\
\hline $5(\mathrm{~S}, \mathrm{P})$ & & $42.77^{\circ} \mathrm{N} / 11.66^{\circ} \mathrm{W}$ & 35.92 & 0.77 & 67.8 & 6.8 & 0.55 & 10.0 & 0.88 & 0.09 & 6.4 & 0.76 & 4.5 & 0.66 \\
\hline $6(S)$ & & $39.45^{\circ} \mathrm{N} / 12.68^{\circ} \mathrm{W}$ & 36.07 & 0.45 & 68.4 & 3.5 & 0.18 & 19.5 & 1.00 & 0.06 & 3.0 & 0.68 & 4.3 & 0.54 \\
\hline $7(\mathrm{~S}, \mathrm{C})$ & & $37.12^{\circ} \mathrm{N} / 13.36^{\circ} \mathrm{W}$ & 36.30 & 0.31 & 70.9 & 1.8 & 0.10 & 41.7 & 0.78 & 0.08 & 1.3 & 0.41 & 2.8 & 0.98 \\
\hline $8(S)$ & & $33.70^{\circ} \mathrm{N} / 14.43^{\circ} \mathrm{W}$ & 36.86 & 0.24 & 70.0 & 8.0 & 0.17 & 8.8 & 1.38 & 0.06 & 2.8 & 0.30 & 2.0 & 0.88 \\
\hline $9(\mathrm{~S}, \mathrm{P})$ & & $30.80^{\circ} \mathrm{N} / 14.93^{\circ} \mathrm{W}$ & 36.89 & 0.15 & 75.4 & 6.8 & 0.11 & 11.1 & 0.83 & 0.06 & 1.8 & 0.40 & 2.7 & 4.15 \\
\hline $10(\mathrm{~S})$ & & $26.68^{\circ} \mathrm{N} / 16.38^{\circ} \mathrm{W}$ & 36.82 & 0.31 & 66.4 & 4.9 & 0.06 & 13.6 & 0.79 & 0.05 & 1.2 & 0.57 & 3.4 & 1.15 \\
\hline $11(\mathrm{~S}, \mathrm{P}, \mathrm{C})$ & NATR & $22.50^{\circ} \mathrm{N} / 20.50^{\circ} \mathrm{W}$ & 36.90 & 0.68 & 69.7 & 5.5 & 0.12 & 12.7 & 0.67 & 0.08 & 1.5 & 0.91 & 6.8 & 2.78 \\
\hline $12(\mathrm{~S})$ & & $17.72^{\circ} \mathrm{N} / 20.81^{\circ} \mathrm{W}$ & 36.46 & 0.45 & 66.7 & 5.8 & $\mathrm{BDL}$ & 11.5 & 0.73 & 0.07 & 0.3 & 0.68 & 5.3 & 2.26 \\
\hline $13(\mathrm{~S}, \mathrm{P})$ & & $14.66^{\circ} \mathrm{N} / 20.98^{\circ} \mathrm{W}$ & 35.55 & 1.42 & 94.7 & 10.3 & 0.23 & 9.2 & 0.40 & 0.07 & 3.2 & 1.69 & 11.8 & 2.58 \\
\hline $14(\mathrm{~S}, \mathrm{C})$ & ETRA & $10.63^{\circ} \mathrm{N} / 20.13^{\circ} \mathrm{W}$ & 35.34 & 0.24 & 80.9 & 4.3 & 0.29 & 18.8 & 1.24 & 0.08 & 3.6 & 0.48 & 3.3 & 4.33 \\
\hline $15(\mathrm{~S})$ & & $8.16^{\circ} \mathrm{N} / 19.19^{\circ} \mathrm{W}$ & 34.47 & 0.22 & 75.3 & 6.9 & 0.17 & 10.9 & 1.26 & 0.06 & 3.1 & 0.50 & 5.1 & 4.74 \\
\hline $16(\mathrm{~S}, \mathrm{P})$ & & $5.43^{\circ} \mathrm{N} / 16.46^{\circ} \mathrm{W}$ & 34.21 & 0.15 & 81.9 & 8.1 & 0.26 & 10.1 & 1.60 & 0.05 & 5.8 & 0.51 & 3.2 & 5.98 \\
\hline $17(\mathrm{~S})$ & & $2.47^{\circ} \mathrm{N} / 14.15^{\circ} \mathrm{W}$ & 34.65 & 0.15 & 79.9 & 5.0 & 0.25 & 15.9 & 0.96 & 0.06 & 4.5 & 0.74 & 5.1 & 4.28 \\
\hline $18(\mathrm{~S})$ & & $0.15^{\circ} \mathrm{S} / 12.19^{\circ} \mathrm{W}$ & 36.03 & 0.14 & 74.3 & 3.1 & 0.08 & 24.0 & 1.06 & 0.06 & 1.3 & 0.55 & 4.3 & 1.20 \\
\hline $19(\mathrm{~S}, \mathrm{P})$ & & $3.17^{\circ} \mathrm{S} / 9.37^{\circ} \mathrm{W}$ & 36.10 & 0.24 & 69.9 & 4.6 & 0.07 & 15.2 & 1.31 & 0.06 & 1.2 & 0.50 & 3.0 & 0.93 \\
\hline $20(\mathrm{~S}, \mathrm{C})$ & & $5.09^{\circ} \mathrm{S} / 7.06^{\circ} \mathrm{W}$ & 36.15 & 0.29 & 72.8 & 3.7 & BDL & 19.8 & 1.21 & 0.11 & 0.2 & 0.73 & 3.9 & 2.44 \\
\hline $21(\mathrm{~S})$ & & $9.08^{\circ} \mathrm{S} / 4.38^{\circ} \mathrm{W}$ & 36.10 & 0.16 & 79.6 & 2.8 & BDL & 28.4 & 1.38 & 0.06 & 0.3 & 0.70 & 3.8 & 0.88 \\
\hline $22(\mathrm{~S}, \mathrm{P})$ & SATL & $11.70^{\circ} \mathrm{S} / 2.14^{\circ} \mathrm{W}$ & 36.41 & 0.11 & 81.0 & 2.2 & 0.08 & 36.8 & 1.17 & 0.07 & 1.1 & 0.46 & 3.2 & 1.45 \\
\hline $23(\mathrm{~S}, \mathrm{P})$ & & $14.95^{\circ} \mathrm{S} / 0.69^{\circ} \mathrm{E}$ & 36.13 & 0.30 & 75.6 & 4.0 & 0.48 & 19.1 & 1.17 & 0.24 & 2.1 & 0.41 & 2.6 & 0.81 \\
\hline $24(\mathrm{~S}, \mathrm{C})$ & & $17.73^{\circ} \mathrm{S} / 3.13^{\circ} \mathrm{E}$ & 35.89 & 0.33 & 70.6 & 4.2 & 2.64 & 16.8 & 1.05 & 0.35 & 7.5 & 1.06 & 6.7 & 0.59 \\
\hline $25(\mathrm{~S})$ & & $20.65^{\circ} \mathrm{S} / 5.73^{\circ} \mathrm{E}$ & 35.54 & 0.40 & 71.9 & 3.5 & 3.86 & 20.5 & 0.93 & 0.51 & 7.6 & 1.23 & 6.8 & 0.55 \\
\hline $26(\mathrm{~S}, \mathrm{C})$ & BENG & $23.72^{\circ} \mathrm{S} / 8.52^{\circ} \mathrm{E}$ & 35.56 & 0.50 & 65.5 & 2.2 & 0.30 & 29.8 & 1.28 & 0.22 & 1.4 & 1.14 & 7.3 & 0.47 \\
\hline
\end{tabular}

a "NM" and "BDL" indicates "not measured" and "below detection limit", respectively; ${ }^{\mathrm{b}} \mathrm{S}, \mathrm{P}$ and C indicates sampling events, i.e., surface water, plankton and deep CTD sampling, respectively; ${ }^{\dagger} \mathrm{DIN}$ includes $\mathrm{NO}_{3}^{-}-\mathrm{N}, \mathrm{NO}_{2}^{-}-\mathrm{N}$ and $\mathrm{NH}_{4}^{+}-\mathrm{N}$ with dominance of $\mathrm{NO}_{3}^{-}-\mathrm{N}$. ${ }^{\mathrm{c}}$ Oceanic provinces are classified according to Longhurst (2006), $\mathrm{NECS}^{-} \mathrm{North}_{\text {East }}$ Atlantic Coastal Shelf, NADR: North Atlantic drift region, NASE: North Atlantic subtropical gyre, NATR: North Atlantic tropical gyre, ETRA: East Tropical Atlantic, SATL: South Atlantic gyre, BENG: Benguela current coastal province.

to Verado et al. (1990). Standard Reference Material 1515 was used for calibration and at least 3 replicates of each sample were measured.

Among the trace elements, total Fe was determined using a liquid-liquid extraction method followed by atomic absorption spectrometry as described by Pohl and Hennings (2005).

\subsection{Determination of bacterial abundance and cultivable Vibrio spp.}

Heterotropic cultivable bacterial counts (CBC) were determined on marine agar (Difco, MI, USA). In case of low cultivable counts, samples were concentrated 500-times (41 to $8 \mathrm{ml}$ ) by filtration $(0.2 \mu \mathrm{m}$ filters, Millipore). Ten $\mathrm{ml}$ of concentrated plankton sample was homogenized with an UltraTurrax (T25, Ika-Werke, Staufen, Germany) prior to bacterial analysis. Selective TCBS (thiosulfate citrate bile salts sucrose) agar (Difco, $3 \% \mathrm{NaCl}$ ) was used for the Vibrio culture. In each case of cultivable counts, a $100 \mu$ l aliquot of sample was spread plated on media in triplicate. Additional filters, each containing concentrated bacteria from a 21 sample, were also subjected to a Vibrio specific enrichment in alkaline peptone water [1\% Bacto-peptone (w/v, Difco), $3 \%$ $\mathrm{NaCl}$ (w/v, Difco), $\mathrm{pH} 8.5$ ] at $25^{\circ} \mathrm{C}$ for $18 \mathrm{~h}$, followed by plating on selective agar plates. Cultivable counts (colony forming unit, $\mathrm{CFU}$ ), were enumerated after $3 \mathrm{~d}$ of incubating the plates in a temperature gradient, i.e., $20^{\circ} \mathrm{C}$ for $12 \mathrm{~h}$ followed by $25^{\circ} \mathrm{C}$ for $12 \mathrm{~h}, 30^{\circ} \mathrm{C}$ for $24 \mathrm{~h}$ and $33^{\circ} \mathrm{C}$ for $24 \mathrm{~h}$ to obtain optimum cultivable cell numbers.

Presumptive Vibrio isolates were verified by oxidase and gelatinase tests followed by partial sequencing $(\sim 800 \mathrm{bp})$ of $16 \mathrm{~S}$ rRNA gene using universal primers (forward 9F, 5'-GAGTTTGATCCTGGCTC-3', and reverse 800R, 5' CTACCAGGGTATCTAAT-3'). Initial PCR products were purified using the QIAQuick PCR purification kit (QIAGEN $\mathrm{GmbH}$, Hilden, Germany), then cycle sequencing was carried out using the BigDye Terminator Cycle Sequencing Kit (Applied Biosystems) in a GeneAmp 9700 thermal cycler (Applied Biosystems) according to the manufacturer's instruction. Afterwards a further purification was done using CleanSEQ (Agencourt Bioscience), and nucleotide sequences were determined in an ABI PRISM 3100 Avant Genetic Analyzer (Applied Biosystems). The sequences were checked for sequence homology to the nearest species by BLAST (http://blast.ncbi.nlm.nih.gov/Blast.cgi). In addition, the isolates were subjected to multiplex PCR analysis for proper screening of some potentially pathogenic and closely-related Vibrio strains (Haldar et al., 2010; Neogi et al., 2010). 
An aliquot of the water samples $(5 \mathrm{ml})$ was fixed with formaldehyde (4\%), stained with 4',6-diamidino-2phenylindole (DAPI) for $30 \mathrm{~min}$ according to the manufacturer's manual (Sigma-Aldrich). Then the abundance of the total culture-independent prokaryotes including the bacterial community was determined following a standard protocol (Porter and Feig, 1980) using an epifluorescence microscope (DM2500, Leica Microsystems). During counting of the cells the numbers of large phytoplankton and zooplankton were excluded to obtain a more realistic assessment of prokaryotic abundance. The term "prokaryote" is used because this method cannot distinguish between bacteria and archaea.

\subsection{Statistical analysis}

The statistical analyses were carried out using "Xact" (version 7.21d, SciLab) and Statistica (ver. 10.0, StatSoft). Regression fits were applied to explore correlations between variables. Log transformed values of bacterial counts were used for the statistical analyses. A p-value of $<0.05$ was considered as significant. Non-metric multi-dimensional scaling (MDS) analysis was performed to elucidate the relationships among bacterial as well as biogeochemical variables in surface water samples $(n=26)$. Non-parametric Spearman rank correlation matrices were used during MDS analysis, and the similarities among the variables were computed by Euclidean distance.

\section{Results}

\subsection{Nutrients and other biogeochemical parameters in surface waters}

The surface water temperature was $13.3^{\circ} \mathrm{C}$ at $\sim 50^{\circ} \mathrm{N}$ near the European shelf, gradually increasing to $29.4^{\circ} \mathrm{C}$ at $\sim 5^{\circ} \mathrm{N}$ in the ETRA province, and then decreasing to $19.0^{\circ} \mathrm{C}$ at the southernmost station in the BENG province. Salinity ranged from 35.2 to 36.9. Chl- $a$ was higher $\left(>0.3 \mu \mathrm{g} \mathrm{l}^{-1}\right)$ between $50^{\circ} \mathrm{N}$ and $37^{\circ} \mathrm{N}$ near the European shelf as well as between $17^{\circ} \mathrm{S}$ and $24^{\circ} \mathrm{S}$, where higher phosphate values $(0.2-0.5 \mu \mathrm{M}$ P) were also found (Table 1). In addition, an increase in Chl- $a$ was observed between $23^{\circ} \mathrm{N}$ and $14^{\circ} \mathrm{N}$ in the NATR province. DIN consisted predominantly of nitrate (60-97\%). Higher DIN values $(>0.5 \mu \mathrm{M})$ were measured at higher latitudes (above $40^{\circ} \mathrm{N}$ and $15^{\circ} \mathrm{S}$, Table 1). The N/P ratio of DIN to DIP (dissolved inorganic phosphorus) was mostly below 3 (0.2 to 3 ), reflecting a nutrient poor environment for primary producers, while the highest ratio (11.6) was near the English Channel $\left(\sim 48^{\circ} \mathrm{N}\right)$ in the NADR province. The concentration of total $\mathrm{Fe}$ varied between 0.5 and $6.0 \mathrm{nM}$, with higher values $(>4)$ in the ITCZ and near $30^{\circ} \mathrm{N}$ (Table 1).
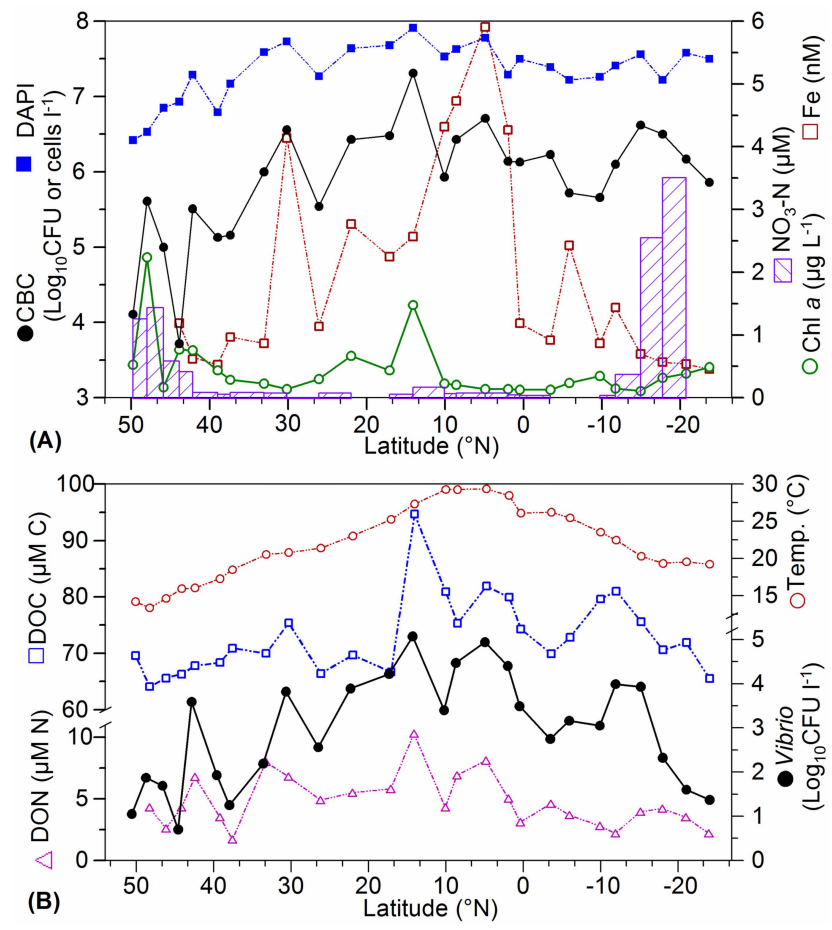

Fig. 2. Fluctuations in bacterial populations and important biogeochemical parameters in surface $(0-10 \mathrm{~m}$ depth) water samples. (A) Changes in culture independent DAPI counts and cultivable bacterial counts $(\mathrm{CBC})$ in comparison with changes in $\mathrm{NO}_{3}^{-}-\mathrm{N}, \mathrm{Fe}$ and chlorophyll- $a(\mathrm{Chl}-a)$. (B) Changes in cultivable Vibrio populations in comparison with temperature (Temp.), dissolved organic $\mathrm{C}$ (DOC) and N (DON). Average values of bacteriological (triplicate) and biogeochemical parameters (quadruplicate) are shown.

DOC concentrations $(64-95 \mu \mathrm{M} \mathrm{C})$ were an order of magnitude higher than DON $(2-10 \mu \mathrm{M} \mathrm{N})$. The $\mathrm{C} / \mathrm{N}$ ratios of DOM were generally below 20 (Table 1). On average, DOC contributed $93 \pm 3 \%$ of total organic C (POC + DOC) while DON represented $87 \pm 12 \%$ of total dissolved N (DIN + DON) and $85 \pm 9 \%$ of total organic N $(\mathrm{DON}+\mathrm{PON})$. Dissolved silicate concentrations fluctuated between 0.4 and $1.6 \mu \mathrm{M}$ with slightly higher values between $10^{\circ} \mathrm{N}$ and $24^{\circ} \mathrm{S}$ (Table 1). The concentrations of POC and PON ranged from $2.0-11.8 \mu \mathrm{M} \mathrm{C}$ and $0.30-1.69 \mu \mathrm{M} \mathrm{N}(\mathrm{Ta}-$ ble 1). The proportion (w/w) of organic $\mathrm{C}$ and $\mathrm{N}$ in the suspended particulate matter was $0.3-4.7 \%$ and $0.03-0.9 \%$, respectively (data not shown).

\subsection{Abundance of total bacteria and Vibrio spp. in surface waters}

The culture independent DAPI counts ranged mostly from $10^{7}$ to $10^{8}$ cells $1^{-1}$, while $\mathrm{CBC}$ varied between $10^{4}$ and $10^{7} \mathrm{CFU}^{-1}$ (Fig. 2a). The fluctuations in CBC followed a similar trend as the DAPI counts, and their abundance was highest at station $13\left(14.66^{\circ} \mathrm{N}\right)$. In most samples, CBC 


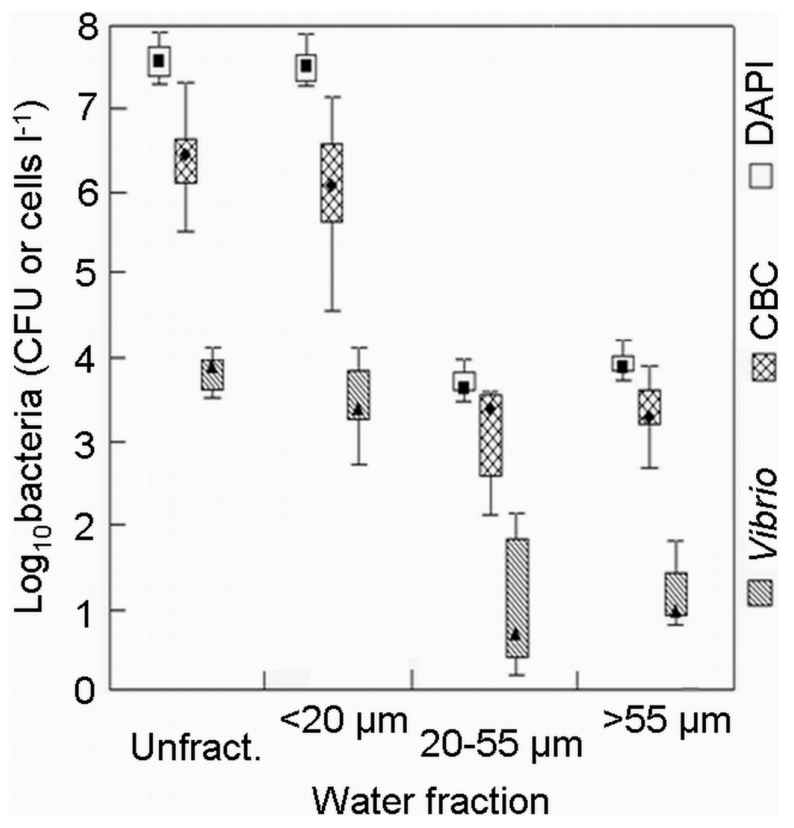

Fig. 3. Abundance of bacteria in surface water fractions $(<20 \mu \mathrm{m}$, 20-55 $\mu \mathrm{m},>55 \mu \mathrm{m}$, unfract.: unfractionated) displayed as box-andwhiskers plots (Statistica). Samples were collected from 9 locations in the eastern Atlantic Ocean. The bottom and top of the box plots indicate the 25th and 75 th percentile. Closed symbols in the box indicate median values. The vertical bars show the standard deviations. DAPI and CBC represent culture independent total prokaryotes and cultivable bacterial counts, respectively. Vibrio represents counts on selective TCBS agar.

represented $0.06-5.0 \%$ of the DAPI counts. Exceptionally high CBC ( $\sim 20 \%$ of the DAPI counts) were observed at $14.66^{\circ} \mathrm{N}$ and $17.73^{\circ} \mathrm{S}$ locations (Fig. 2a). The Vibrio abundance varied between $10^{2}$ and $10^{4} \mathrm{CFU}^{-1}$, accounting $0.02-1.8 \%$ of $\mathrm{CBC}$, while comparatively higher counts $\left(\sim 10^{5} \mathrm{CFU}^{-1}\right)$ were observed at $14.66^{\circ} \mathrm{N}$ and $5.43^{\circ} \mathrm{N}$ (Fig. 2b). Near the European shelf $\left(50^{\circ} \mathrm{N}-37^{\circ} \mathrm{N}\right)$, where the surface water temperature was $<18^{\circ} \mathrm{C}$, cultivable Vibrio counts were comparatively low $\left(<10^{2} \mathrm{CFU}^{-1}\right)$ except at $42.77^{\circ} \mathrm{N}$ (Fig. 2b). Sequencing of the $16 \mathrm{~S}$ rRNA genes of representative Vibrio isolates $(n=215)$ followed by multiplex PCR detection revealed that the cultivable populations were dominated by V. campbellii (36\%) followed by V. alginolyticus $(25 \%), V$. harveyi $(17 \%)$ and V. corallilyticus $(11 \%)$, while among others $V$. natriegens, $V$. pelagius and $V$. splendidus were only present in low numbers $(<2 \%)$. At each sampling location the cultivable Vibrio portion was overwhelmingly dominated by only one to three species.

The comparative analysis of the bacterial abundance in the fractionated samples revealed that most bacteria were present in the $<20 \mu \mathrm{m}$ fraction (Fig. 3). This general trend was found in all nine different geographic locations (Fig. 1). The Vibrio abundance ranged mostly between $10^{3}$ and $10^{4} \mathrm{CFU}^{-1}$ in the $<20 \mu \mathrm{m}$ fraction, while in the $20-55 \mu \mathrm{m}$ and $>55 \mu \mathrm{m}$

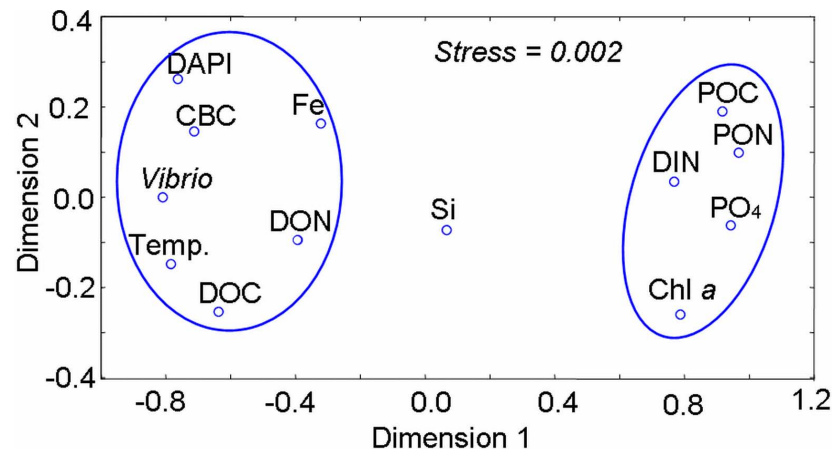

Fig. 4. Multi-dimensional scaling analysis of surface water sample data $(n=26)$ including bacteriological parameters (DAPI, CBC and Vibrio) and biogeochemical parameters (DIN: dissolved inorganic $\mathrm{N}$, POC and PON: particulate organic $\mathrm{C}$ and $\mathrm{N}$, respectively, for other abbreviations refer to Fig. 2). Variables having close affinity or strong correlation are encircled.

fractions the counts were very low $\left(<10^{2} \mathrm{CFU}^{-1}\right)$. A higher abundance of DAPI-stained prokaryotes and higher CBC were also observed in the $<20 \mu \mathrm{m}$ fraction (Fig. 3). In the $>20 \mu \mathrm{m}$ fraction of the samples, a large portion of the associated bacteria (10-60\% of DAPI counts) remained in cultivable form.

\subsection{Relationship between bacterial abundance and biogeochemical parameters in surface waters}

Multivariate analysis showed that bacterial counts in surface waters were independent of particulate parameters such as Chl- $a$, POC and PON (Fig. 4). However, DAPI counts, CBC and Vibrio grouped with temperature, DOC, DON and $\mathrm{Fe}$ indicating the probable influence of these biogeochemical parameters on bacterial abundance. In particular, a close linkage between Vibrio, temperature, DOC and DON was discernible (Fig. 4). A highly significant positive correlation was observed between water temperature and bacterial counts (DAPI: $r=0.75, p<0.001$; CBC: $r=0.67, p<$ 0.001 , Fig. 5a and b). However, our data revealed an even stronger and more significant correlation between water temperature and cultivable Vibrio spp. $(r=0.76, p<0.00005$, Fig. 5c).

A strong correlation between particulate parameters (Chl$a, \mathrm{POC}$ and PON) and inorganic nutrients (Fig. 4) was in congruence with the higher concentrations of all these parameters at the most northerly and southerly stations (Table 1, Fig. 2a). POC correlated highly significantly with PON $(r=0.90, p<0.00001$, not shown), with an average $\mathrm{C} / \mathrm{N}$ ratio of 6.4 suggesting phytoplankton as the primary source of POM (Redfield et al., 1963). Intriguingly, DOC and temperature were highly significantly correlated $(r=0.66$, $p<0.0005$, Fig. 5d), but there was no correlation between temperature and the particulate parameters (Fig. 4). 

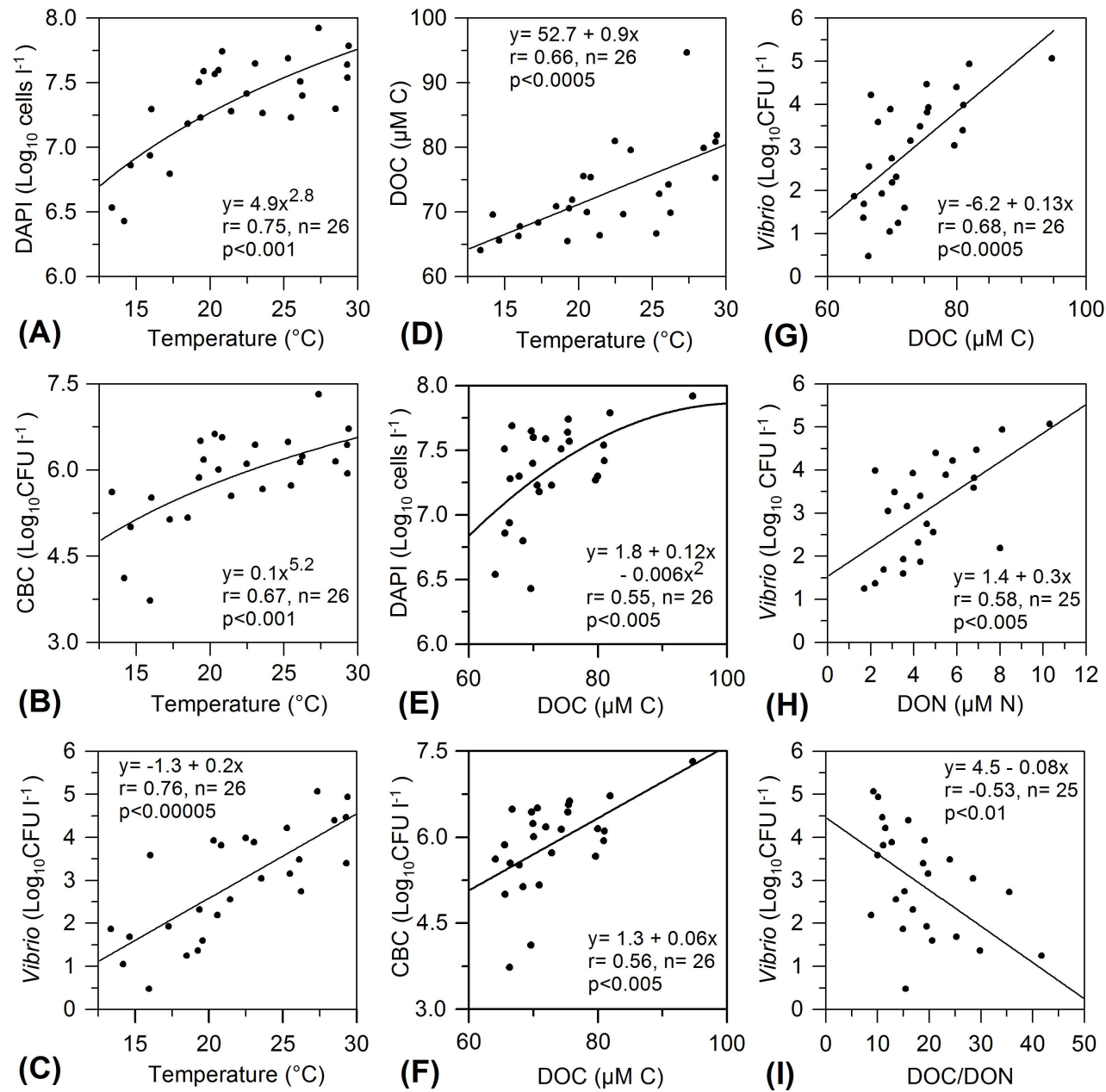

Fig. 5. Correlations between bacterial abundance and various biogeochemical factors in all surface water samples. The lines represent linear or curvilinear regressions between the two parameters. The regression equations and relevant statistical information are shown for each correlation. For abbreviations refer to Fig. 2.

Among the bacterial variables cultivable Vibrio correlated highly significantly with DOC $(r=0.68, p<0.0005$, Fig. 5g) and DON ( $r=0.58, p<0.005$, Fig. 5h). Cultivable Vibrio abundance exhibited a negative correlation with the $\mathrm{C} / \mathrm{N}$ ratio of DOM ( $r=-0.53, p<0.01$, Fig. $5 \mathrm{i})$. The overall prokaryotic counts represented by DAPI and CBC also correlated positively with DOC $(r=0.55, p<0.005$ and $r=0.56, p<0.005$, respectively, Fig. 5e and f) and DON ( $r=0.55, p<0.005$ and $r=0.51, p<0.01$, respectively), but the correlations were less strong in comparison with cultivable Vibrio.

Although temperature had a strong influence on CBC including Vibrio populations, the bacterial counts at some sampling locations showed unexpected variations. These patterns of spatial variations in bacterial counts were congruent with the variations in DOC and DON (Fig. 2). For example, at station $5\left(42.77^{\circ} \mathrm{N}\right)$ the water temperature was low $\left(<16^{\circ} \mathrm{C}\right)$ but there were high Vibrio counts that coincided with a relatively high DON concentration. Similarly, moving south from the equator towards station $22\left(11.70^{\circ} \mathrm{S}\right)$, the temperature followed a gradually decreasing trend, but there was a spike in Vibrio populations at this latitude that coincided with an increase in DOC (Fig. 2b). Increases in bacterial abundance also coincided with the higher Fe concentration at $30^{\circ} \mathrm{N}$ and in the ITCZ (Fig. 2). In contrast, the abundance of prokaryotes including cultivable Vibrio spp. in surface waters did not correlate with the dissolved inorganic nutrients, e.g., phosphate, nitrate, nitrite and ammonium.

\subsection{Depth variations in bacterial abundance and biogeochemical parameters}

Samples from the deep ocean (Fig. 1) were categorized into surface (0-10 m), lower euphotic (50-200 m, including samples from fluorescence [Chl- $a$ ] maximum layer at stations 11, 14, 20 and 24), mesopelagic (1000-2500 m) and abyssal 

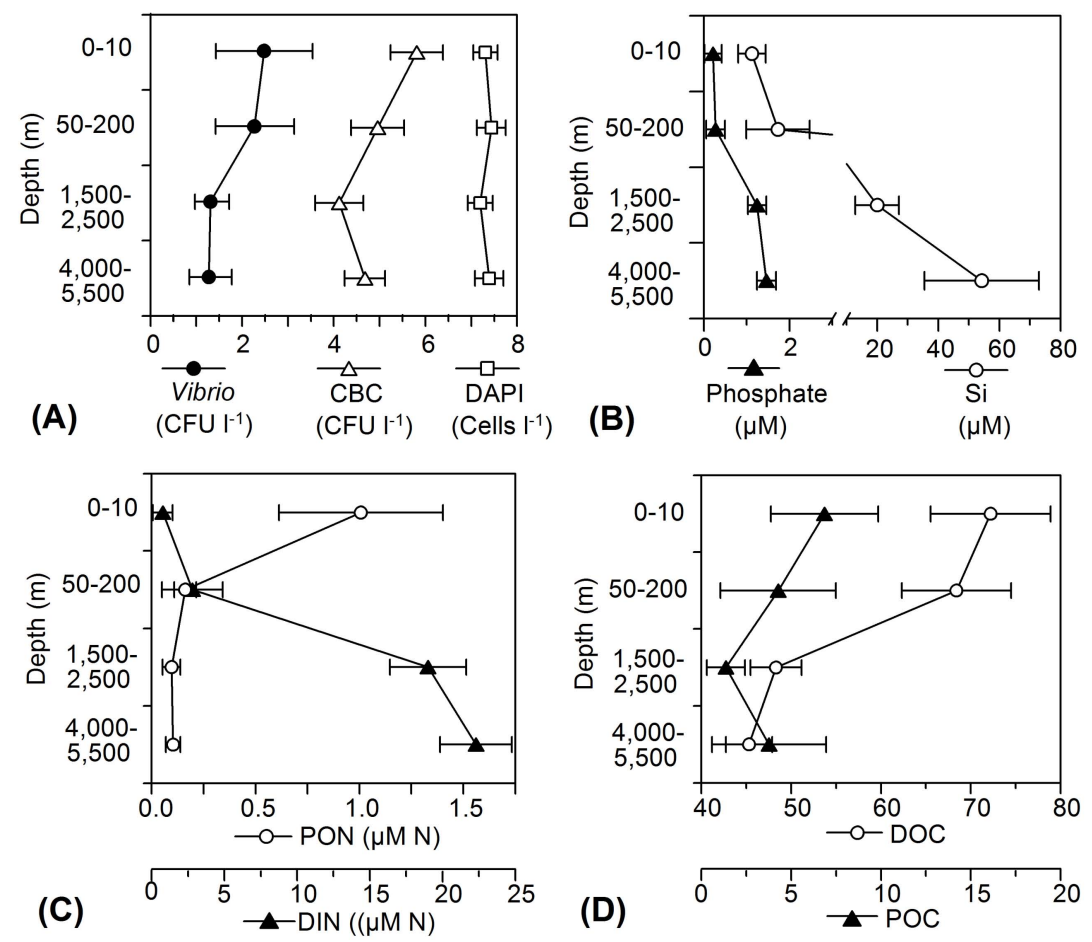

Fig. 6. Depth-wise changes in bacterial abundance and biogeochemical parameters. Samples were collected at 7 locations in the eastern Atlantic Ocean. Symbols and horizontal bars indicate average and standard deviation, respectively. For abbreviations refer to Fig. 2 and 4.

(4000-5500 m) zones. The temperature gradually decreased to $3.1-5.8^{\circ} \mathrm{C}$ and $1.1-2.5^{\circ} \mathrm{C}$ in the mesopelagic and abyssal zones, respectively. At stations in the northern and southern extremes (above $40^{\circ} \mathrm{N}$ and $15^{\circ} \mathrm{S}$ ), the existence of a thermocline in the euphotic zone was not obvious. In contrast, in the tropical regions, particularly between $15^{\circ} \mathrm{N}$ and $12^{\circ} \mathrm{S}$, a prominent thermocline was observed, where rapid drastic temperature changes of $10-15^{\circ} \mathrm{C}$ occurred within $150 \mathrm{~m}$ depth.

DAPI counts did not show any conspicuous changes with depth but $\mathrm{CBC}$ gradually decreased (Fig. 6a). $\mathrm{CBC}$ at the surface $\left(10^{4}-10^{7} \mathrm{CFU}^{-1}\right)$ was 50 to 100 times higher than in the pelagic zone $\left(10^{3}-10^{5} \mathrm{CFU}^{-1}\right)$. A small increase in $\mathrm{CBC}$ was observed near the seafloor compared to the mesopelagic zone. In the fluorescence maximum layer (50$200 \mathrm{~m}$ ) of the euphotic zone, the abundance of CBC including Vibrio spp. was 5-10 times lower than in surface waters, although DAPI counts were similar. Vibrio abundance was at least 10 times lower in the mesopelagic and abyssal zones (average $\sim 10 \mathrm{CFU}^{-1}$ ) than at the surface (Fig. 6a).

Inorganic nutrients gradually increased with depth, and the highest values were always near the seafloor (Fig. 6b and c). The variations in nutrients in the surface waters of the various biogeochemical provinces are shown in Table 1 . In the bathypelagic samples near the seafloor, phosphate, silicate and DIN values were more than 5, 30 and 20 times higher than the surface concentrations, respectively. PON decreased sharply from an average of $\sim 1.0 \mu \mathrm{MN}$ at the surface to $\sim 0.2 \mu \mathrm{M} \mathrm{N}$ or less below the euphotic zone (Fig. 6c). POC also decreased gradually with depth (e.g., 3-10 $\mu \mathrm{MC}$ at the surface to $0.1-$ $2.5 \mu \mathrm{MC}$ in the mesopelagic zone). However, more variable and higher POC values $(0.2-7 \mu \mathrm{M} \mathrm{C})$ were observed near the sea-floor than in the mesopelagic zone (Fig. 6d). The results from this limited number of samples did not reveal any statistically significant relation between bacterial abundance (DAPI-count, CBC and cultivable Vibrio) and POC or DOC values in the meso- and bathypelagic waters. DOC also showed a gradual depth-wise decrease, e.g., $65-80 \mu \mathrm{MC}$ at the surface and 40-47 $\mu \mathrm{MC}$ near the sea floor (Fig. 6d).

\section{Discussion}

The present study shows that bacterial dynamics in the eastern Atlantic Ocean are consistently linked to the changes in organic matter and temperature. A considerable fraction of the bacterial community was cultivable, not only in surface waters but also in cold waters at great depths. The fluctuations in abundance of cultivable Vibrio in line with changes in a number of important biogeochemical parameters indicate that this group of bacteria can potentially make an important contribution to the turnover of organic $\mathrm{C}$ and $\mathrm{N}$ in the open ocean. 


\subsection{Role of POM on bacterial dynamics in surface waters}

In the nutrient-limited oceanic environment, particulate matter in form of aggregates or marine snow can support part of the bacterial community (Azam and Long, 2001). Heterotrophic bacteria in the photic zone are genetically adapted to compete for nutrients by moving towards nutrient-rich particles and algae (DeLong et al., 2006). However, our study indicates a passive role of POM in regulating bacterial abundance in oceanic surface waters. Our observation that there is no correlation with particulate parameters is congruent with the inference that bacterial $\mathrm{C}$ demand exceeds photosynthetic production of POC in the marine environment (del Giorgio and Duarte, 2002). The Chl- $a$ concentrations at the majority of stations were very low, except in the nutrient-rich northern and southern extremes and at some central stations in the NATR province. A similar trend of declining PP in response to the exhaustion of DIN has been reported previously (Hoppe et al., 2002).

Larger phytoplankton $(>20 \mu \mathrm{m})$ and zooplankton $(>55 \mu \mathrm{m})$ played a minor role in harboring bacteria including Vibrio spp. and most prokaryotes $(>99 \%)$ were found in the $<20 \mu \mathrm{m}$ fraction (Fig. 3). Smaller particles $(<20 \mu \mathrm{m}$, including pico- and nanoplankton) and/or DOM are probably the main sources of bacterial nutrients. A recent finding shows that most of the Vibrio population in the coastal habitat occurs in the $<20 \mu \mathrm{m}$ fraction (Lara et al., 2011). Pigment composition analysis has revealed that the photosynthetic pico- and nanoplankton are the dominant primary producers in the Atlantic surface water (Taylor et al., 2011). Nevertheless, a positive correlation between bacterial abundance and Chl- $a$ was not discernible in our study. This indicates a major role of DOM in nourishing bacterial populations in the eastern Atlantic Ocean. Higher bacterial production also coincided with peaks in $\mathrm{Fe}$ at some locations (Fig. 2). As there was a strong correlation between the Fe concentrations in aerosols and surface waters during the same cruise (Schmitt-Kopplin, unpublished data), atmospheric input of Saharan dust is the most likely source of the high Fe concentrations, which may increase PP, particularly in the ITCZ (Pohl et al., 2011). Freshly produced POM can also be quickly degraded to DOM by bacteria generating a possible time-lag between POM and bacterial dynamics in surface waters.

\subsection{Temperature influence on DOC production and bacterial abundance}

Both abundance of prokaryotes, including Vibrio spp., and DOC were significantly correlated with temperature in the Atlantic Ocean. Bacteria including Vibrio spp. in surface waters may make significant use of DOM, here quantified as DOC or DON, to facilitate their survival without being associated with larger plankton (Figs. 3, 4). However, at higher temperatures, bacteria exhibit higher metabolic rates and are also able to degrade organic substrates more rapidly (Pomeroy and Wiebe, 2001). This is a plausible explanation for the positive correlation between DOC and temperature. Bacteria also produce semi-labile and refractory DOC during organic matter degradation (Ogawa et al., 2001; Gruber et al., 2006). Therefore, part of the correlation between DOC and temperature could also be explained by the microbial generation of DOM. In addition, the vertical stratification of the upper water column of tropical and subtropical oceans favors the high DOC concentration (Hansell et al., 2009). Comparatively low DOC and DON concentrations in the highly productive northern and southern extremes might be due to a decrease in bacterial degradation capacity at low temperatures. Moreover, bacteria may require more DOM to grow at low temperatures $\left(10-15^{\circ} \mathrm{C}\right)$ than at high temperatures $\left(>20^{\circ} \mathrm{C}\right)$ (Wiebe et al., 1993). A combination of higher temperature and increased PP can also boost DOM (DOC and DON) concentration and bacterial abundance in tropical regions (e.g., $14.66^{\circ} \mathrm{N}$, Table 1, Fig. 2). It has been shown that DOM (e.g., glucose) and higher temperature may synergistically act on marine bacterial growth in laboratory microcosm experiments (Kirchman and Rich, 1997).

\subsection{Vertical changes in biogeochemical profile and abundance of Vibrio and other bacteria}

The depth-wise decrease in DOC (Fig. 6d) indicated its "semi-refractory" nature. The persistence of semi-labile DOC (e.g., carbohydrates in a complex matrix) in the oldest bottom waters has been confirmed by spectroscopic and chemical analyses (Hansell et al., 2009). When considering the overall oceanic DOC, a high proportion $(>90 \%)$ is recalcitrant (Jiao et al., 2010). However, the highly significant positive correlation of DOC with the Vibrio abundance in the Atlantic surface waters suggests that labile or semi-labile DOC play a vital role in the survival and growth of Vibrio spp. and other bacteria. Molecular analyses have confirmed that the majority of the degradation of DOM occurs in the surface water (Flerus et al., 2011). The upward flux of inorganic $\mathrm{N}$ may not be sufficient to meet the biological demands in the surface layer, thus Vibrio spp. as well as other prokaryotes may largely depend on DON availability and recycling (e.g., Fig. 5h). The temporal or seasonal fluctuations in PP in the surface layer of the different oceanic provinces may ultimately contribute to the variability in some biogeochemical parameters (e.g., POC) at various oceanic depths. We did not find any conspicuous depth-wise variation in DAPI-counts and likewise no relation between prokaryotic abundance and POC concentrations. There was a depth-wise decrease in CBC and Vibrio abundance but no significant correlation was discernible between POC and these bacterial variables. Nevertheless, the decrease in PON and POC from the surface towards the mesopelagic zone confirms the dissolution of sinking POM to support bacterial metabolism. Other studies have 
reported that prokaryotic abundance decreases by one order of magnitude from the lower euphotic zone to the bathypelagic waters where bacterial activity or production is generally influenced by the dynamics of POM (Arístegui et al., 2009; Baltar et al., 2009a; Bochdansky et al., 2010). Extensive molecular analyses have shown the genetic potential of microbial communities to lead a surface-attached lifestyle in the meso- and bathypelagic zones (DeLong et al., 2006).

The lower CBC and Vibrio abundance in the deep sea in comparison with surface waters (Fig. 6a) is presumably due to the low temperature and scarcity of bioavailable organic substrates. Even in the fluorescence maximum zones at 50$200 \mathrm{~m}$ depth, characterized by higher POM but lower temperatures than in the surface waters, there was no significant difference in DAPI counts, but CBC was much lower in these zones than in the surface waters. The abundance of cultivable Vibrio at the Atlantic surface was lower than has generally been observed in eutrophic estuarine and near-shore habitats (Mahmud et al., 2007, 2008; Lara et al., 2009). Nonetheless, the present study indicates that Vibrio spp. are well adapted to oligotrohic oceanic habitats including mesopelagic and bottom waters. In fact, our study is a pioneering effort to quantify cultivable Vibrio spp. from various depths of the ocean. The depth profiles of DOC and inorganic nutrients were opposite, which suggests bacterial mineralization of sinking organic material. Intriguingly, the persistence of a large number of DAPI-stained cells $\left(\sim 10^{7}\right.$ cells $\left.1^{-1}\right)$ across all oceanic depths indicates that deep sea prokaryotes exist predominantly in non-cultivable form and may utilize semilabile DOM for their survival. However, the examination of the oceanic samples by fluorescence in situ hybridization and microautoradiography indicated a depth-wise decrease in the proportion of live or metabolically active bacterial populations, e.g., 30-60\% of the DAPI-stained cells were metabolically active in the euphotic zone and only $2-20 \%$ in the bathypelagic zone (Teira et al., 2004; Baltar et al., 2010). Interestingly, a recent study has discovered that the cell-specific extracellular enzymatic activity and respiration rates increase with oceanic depth, which may facilitate the utilization of deep ocean organic matter by bacterial communities (Baltar et al., 2009b).

\subsection{DOM as an important regulator of Vibrio and other bacterial dynamics}

The present study indicates that cultivable Vibrio and the abundance of other bacteria in the Atlantic Ocean are presumably influenced by the concentrations and characteristics of DOM, in addition to the influence of POM. The low DOC/DON ratio (mostly between 9 and 20) at the ocean surface suggests that autochthonous plankton are the primary source of DOM. Freshly produced DOM from marine phytoplankton has low $\mathrm{C} / \mathrm{N}$ values ranging from 4 to 11 (Hopkinson et al., 1997; Conan et al., 2007). Labile DOM is also characterized by lower $\mathrm{C} / \mathrm{N}$ values than refractory $\mathrm{DOM}$
(Carlson, 2002). Our study has revealed a higher Vibrio abundance in surface samples where DOM exhibits low $\mathrm{C} / \mathrm{N}$ values. The association of vibrios with plankton or suspended particulates in order to utilize released DOM can be facilitated by flagella, pili, chemotaxis, and quorum sensing (Yildiz and Visick, 2009). The exceptional higher occurrence of cultivable bacteria ( $\sim 20 \%$ of DAPI count) in some tropical mid-Atlantic regions with higher DOC and DON values (e.g., $14.66^{\circ} \mathrm{N}$ ) indicates their potential to resuscitate from the predominant non-cultivable state probably in response to the availability of degradable DOM.

Individual or combined changes in DOC and DON in combination with temperature provide a better explanation than temperature alone for variations in bacterial abundance, particularly Vibrio spp. Microcosm studies have shown that Vibrio spp. can grow faster than other prokaryotes due to their more efficient utilization of DOM, and thus may aid in their persistence in particle-free seawater (Mouriño-Pérez et al., 2003; Weinbauer et al., 2006). Our study has also revealed that the oceanic Vibrio populations correlated more strongly with DOC and DON than total prokaryotes represented by DAPI or CBC. Thus, temperature alone may not properly explain the dynamics of Vibrio and other prokaryotes in oceanic surface water and the effects of DOC, DON and PP need also to be considered. The occurrence of higher DOC and DON concentrations at some eastern Atlantic stations did not correlate with Chl- $a$ but coincided with higher Fe values or lower salinities (e.g., $2-15^{\circ} \mathrm{N}$ ). Cross-shelf rapid export of recently fixed organic matter to the offshore ocean environment via numerous upwelling filaments is an important cause of elevated concentrations of DOM in surface waters of the eastern North Atlantic (Barton et al., 1998, 2004; GarcíaMuñoz et al., 2004; Álvarez-Salgado et al., 2007). The exceptionally high values of DOM, Chl- $a$ as well as cultivable bacterial abundance at $14.66^{\circ} \mathrm{N}$ were most likely due to the entrainment of upwelling filament waters. Higher Chl- $a$ concentrations at $17^{\circ} \mathrm{N}$ and $22^{\circ} \mathrm{N}$ may also be due to the entrainment of upwelling waters (Arístegui et al., 2004), although DOC, Vibrio and the overall prokaryotic abundance did not change accordingly. Apart from the effect of offshore transport, atmospheric input of high $\mathrm{Fe}$ concentrations may facilitate fast plankton growth followed by its degradation and production of DOM to support the heterotrophic bacterial community. In this context, the bioavailability and solubility of iron may play an important role (Jickells et al., 2005; Boyanapalli et al., 2007). In a recent microcosm experiment, the addition of atmospheric dust caused a drastic increase (12fold) in the pathogenic Vibrio cholerae population within a day (Lipp and Westrich, 2011). The low abundance of particulate sources of $\mathrm{C}$ and $\mathrm{N}$ (DOC $=93 \pm 3 \%$ of total organic C, DON $=85 \pm 9 \%$ of total organic $\mathrm{N}$ ) at the surface suggests the presence of old DOM which may be mostly semi-labile or refractory. However, in regions with higher solar irradiation refractory DOM can be photochemically degraded into more labile and low molecular weight DOC, which might 
be used directly by Vibrio and other bacteria (Kieber et al., 1989; Cherrier et al., 1999).

\section{Conclusions}

Our study illustrates an important role of DOM in regulating marine bacterial populations, particularly Vibrio spp. Most bacteria can survive without being associated with plankton $(>20 \mu \mathrm{m})$ and seems to be not directly dependent on POC or PON, although phytoplankton or, more general, suspended particulate matter is the primary source of DOM. Therefore, it appears likely that DOC and DON are important sources of carbon and nitrogen for oceanic bacterial growth and survival. The correlations between temperature, DOC, DON and prokaryotic abundance including cultivable Vibrio spp. in the Atlantic surface waters support this hypothesis. Bacterial influence on the turnover of semi-labile DOM might be very important. The ubiquitous presence of cultivable Vibrio spp. in surface and deep sea waters identifies this bacterial group as one of the key players in biogeochemical cycles. Rising temperatures due to global warming may increase the abundance of marine bacteria including opportunistic Vibrio spp. and facilitate degradation of labile and semi-labile organic matter and thus the conservation of fixed carbon as refractory DOM. More research is required into the complex interplay of temperature, DOC, DON and bacterial utilization of DOM for a better understanding of the role of organic matter in supporting bacterial dynamics in the oligotrophic oceanic environment.

Acknowledgements. This study was performed in partial fulfillment of the requirements of a PhD thesis for S. B. Neogi from Graduate School of Life and Environmental Sciences, Osaka Prefecture University, Osaka, Japan. This collaborative work was funded by the AWI, Bremerhaven, Germany and the Leibniz-ZMT GmbH, Bremen, Germany. Crew members onboard R/V Polarstern are sincerely thanked for their help. We thank Dieter Peterke (ZMT) for his technical assistance during sample processing.

Edited by: G. Herndl

\section{References}

Alderkamp, A. C., van Rijssel, M., and Bolhuis, H.: Characterization of marine bacteria and the activity of their enzyme systems involved in degradation of the algal storage glucan laminarin, FEMS Microbiol. Ecol., 59, 108-117, 2007.

Álvarez-Salgado, X. A., Arístegui, J., Barton, E. D., and Hansell, D. A.: Contribution of upwelling filaments to offshore carbon export in the subtropical Northeast Atlantic Ocean, Limnol. Oceanogr., 52, 1287-1292, 2007.

Arístegui, J., Barton, E. D., Tett, P., Montero, M. F., GarcíaMuñoz, M., Basterretxea, G., Cussatlegras, A.-S., Ojeda, A., and De Armas, D.: Variability in plankton community structure, metabolism, and vertical carbon fluxes along an upwelling filament (Cape Juby, NW Africa), Prog. Oceanogr., 62, 95-113, 2004.

Arístegui, J., Gasol, J. M., Duarte, C. M., and Herndl, G. J.: Microbial oceanography of the dark ocean's pelagic realm, Limnol. Oceanogr., 54, 1501-1529, 2009.

Azam, F.: Microbial control of oceanic carbon flux: the plot thickens, Science, 280, 694-696, 1998.

Azam, F. and Long, R. A.: Sea snow microcosms, Nature, 414, 495-498, 2001.

Baltar, F., Arístegui, J., Gasol, J. M., Sintes, E., and Herndl, G. J.: Evidence of prokaryotic metabolism on suspended particulate organic matter in the dark waters of the subtropical North Atlantic, Limnol. Oceanogr., 54, 182-193, 2009a.

Baltar, F., Arístegui, J., Sintes, E., van Aken, H. M., Gasol, J. M., and Herndl, G. J.: Prokaryotic extracellular enzymatic activity in relation to biomass production and respiration in the mesoand bathypelagic waters of the (sub)tropical Atlantic, Environ. Microbiol., 11, 1998-2014, 2009b.

Baltar, F., Arístegui, J., Gasol, J. M., Lekunberri, I., and Herndl, G. J.: Mesoscale eddies: hotspots of prokaryotic activity and differential community structure in the ocean, ISME J., 4, 975988, 2010.

Barton, E. D., Aristegui, J., Tett, P., Canton, M., García-Braun, J., Hernández-León, S., Nykjaer, L., Almeida, C., Almunia, J., Ballesteros, S., Basterretxea, G., Escanez, J., García-Weill, L., Hernández-Guerra, A., López-Laatzen, F., Molina, R., Montero, M. F., Navarro-Peréz, E., Rodríguez, J. M., Van Lenning, K., Vélez, H., and Wild, K.: The transition zone of the Canary Current upwelling region, Prog. Oceanogr., 41, 455-504, 1998.

Barton, E. D., Arístegui, J., Tett, P., and Navarro-Pérez, E.: Variability in the Canary Islands area of filament-eddy exchanges, Prog. Oceanogr., 62, 71-94, 2004.

Bochdansky, A. B., van Aken, H. M., and Herndl, G. J.: Role of macroscopic particles in deep-sea oxygen consumption, Proc. Natl. Acad. Sci. U S A., 107, 8287-8291, 2010.

Boyanapalli, R., Bullerjahn, G. S., Pohl, C., Croot, P. L., Boyd, P. W., and McKay, R. M. L.: A luminescent whole-cell cyanobacterial bioreporter for measuring Fe availability in diverse marine environments, Appl. Environ. Microbiol., 73, 1019-1024, 2007.

Carlson, C. A.: Production and removal processes, in: Biogeochemistry of Marine Dissolved Organic Matter, edited by Hansell D.A. and Carlson, C.A., Elsevier Science, USA, New York, 91-151, 2002.

Cherrier, J., Bauer, J. E., Druffel, E. R. M., Coffin, R. B., and Chanton, J. P.: Radiocarbon in marine bacteria: evidence for the ages of assimilated carbon, Limnol. Oceanogr., 44, 730-736, 1999.

Conan, P., Søndergaard, M., Kragh, T., Thingstad, F., Pujo-Pay, M., Williams, P. J., Le, B., Markager, S., Cauwet, G., Borch, N. H., Evans, D., and Riemann, B.: Partitioning of organic production in marine plankton communities: the effects of inorganic nutrient ratios and community composition on new dissolved organic matter, Limnol. Oceanogr., 52, 753-765, 2007.

Constantin de Magny, G., Murtugudde, R., Sapiano, M. R., Nizam, A., Brown, C. W., Busalacchi, A. J., Yunus, M., Nair, G. B., Gil, A. I., Lanata, C. F., Calkins, J., Manna, B., Rajendran, K., Bhattacharya, M. K., Huqm A., Sack, R. B., and Colwell, R. R.: Environmental signatures associated with cholera epidemics., Proc. Natl. Acad. Sci. USA., 105, 17676-17681, 2008. 
del Giorgio, P. A. and Duarte, C. M.: Respiration in the open ocean, Nature, 420, 379-384, 2002.

DeLong, E. F., Preston, C. M., Mincer, T., Rich, V., Hallam, S. J., Frigaard, N. U., Martinez, A., Sullivan, M. B., Edwards, R., Brito, B. R., Chisholm, S. W., and Karl, D. M.: Community genomics among stratified microbial assemblages in the ocean's interior, Science, 311, 496-503, 2006.

Eilers, H., Pernthaler, J., Glöckner, F. O., and Amann, R.: Culturability and In situ abundance of pelagic bacteria from the North Sea, Appl. Environ. Microbiol., 66, 3044-3051, 2000.

Flerus, R., Koch, B. P., Lechtenfeld, O. J., McCallister, S. L., Schmitt-Kopplin, P., Benner, R., Kaiser, K., and Kattner, G: A molecular perspective on the ageing of marine dissolved organic matter, Biogeosciences Discuss., 8, 1145311488, doi:10.5194/bgd-8-11453-2011, 2011.

García-Muñoz, M., Arístegui, J., Montero, M. F., and Barton, E. D.: Distribution and transport of organic matter along a filamenteddy system in the Canaries - NW Africa coastal transition zone region, Prog. Oceanogr., 62, 115-129, 2004.

Gruber, D. F., Simjouw, J. P., Seitzinger, S. P., and Taghon, G. L.: Dynamics and characterization of refractory dissolved organic matter produced by a pure bacterial culture in an experimental predator-prey system, Appl. Environ. Microbiol., 72, 41844191, 2006.

Haldar, S., Neogi, S. B., Kogure, K., Chatterjee, S., Chowdhury, N., Hinenoya, A., Asakura, M., and Yamasaki, S: Development of a haemolysin gene-based multiplex PCR for simultaneous detection of Vibrio campbellii, Vibrio harveyi and Vibrio parahaemolyticus, Lett. Appl. Microbiol., 50, 146-152, 2010.

Hansell, D. A., Carlson, C. A., Repeta, D. J., and Shlitzer, R.: Dissolved organic matter in the ocean: a controversy stimulates new insights, Oceanography, 22, 202-211, 2009.

Heidelberg, J. F., Heidelberg, K. B., and Colwell, R. R.: Seasonality of Chesapeake Bay bacterioplankton species, Appl. Environ. Microbiol., 68, 5488-5497, 2002.

Hopkinson, C. S., Fry, B., and Nolin, A. L.: Stoichiometry of dissolved organic matter dynamics on the continental shelf of the northeastern U.S.A., Cont. Shelf Res., 17, 473-489, 1997.

Hoppe, H. G., Gocke, K., Koppe, R., and Begler, C.: Bacterial growth and primary production along a north-south transect of the Atlantic Ocean, Nature, 416, 168-171, 2002.

Jiao, N., Herndl, G. J., Hansell, D. A., Benner, R., Kattner, G., Wilhelm, S. W., Kirchman, D. L., Weinbauer, M. G., Luo, T., Chen, F., and Azam, F.: Microbial production of recalcitrant dissolved organic matter: long-term carbon storage in the global ocean, Nat. Rev. Microbiol., 8, 593-599, 2010.

Jickells, T. D., An, Z. S., Andersen, K. K., Baker, A. R., Bergametti, G., Brooks, N., Cao, J. J., Boyd, P. W., Duce, R. A., Hunter, K. A., Kawahata, H., Kubilay, N., laRoche, J., Liss, P. S., Mahowald, N., Prospero, J. M., Ridgwell, A. J., Tegen, I., and Torres, R.: Global iron connections between desert dust, ocean biogeochemistry, and climate, Science, 308, 67-71, 2005.

Kattner, G., and Becker, H.: Nutrients and organic nitrogenous compounds in the marginal ice zone of the Fram Strait, J. Mar. Syst. 2, 385-394, 1991.

Kattner, G.: Storage of dissolved inorganic nutrients in seawater: Poisoning with mercuric chloride, Mar. Chem. 67, 61-66, 1999.

Kieber, D., McDaniel, J., and Mopper K: Photochemical source of biological substrates in seawater: implications for carbon cy- cling, Nature, 341, 637-639, 1989.

Kirchman, D. L., and Rich, J. H.: Regulation of bacterial growth by dissolved organic carbon and temperature in the Equatorial Pacific Ocean, Microb. Ecol. 33, 11-20, 1997.

Koroleff, K.: Determination of phosphate, ammonia and silicon, edited by: Grasshoff, K., Ehrhardt, M., Kremling, K., Methods of seawater analyses, Verlag Chemie, 125-183, 1983.

Lara, R. J., Neogi, S. B., Islam, S., Mahmud, Z. H., Yamasaki, S., and Nair, G. B.: Influence of estuarine dynamics and catastrophic climatic events on Vibrio distribution in the Karnaphuli Estuary, Bangladesh, EcoHealth, 6, 279-286, 2009.

Lara, R. J., Neogi, S. B., Islam, S., Mahmud, Z. H., Islam, S., Paul, D., Demoz, B. B., Yamasaki, S., Nair, G. B., and Kattner, G.: Vibrio cholerae in waters of the Sunderban mangrove: relationship with biogeochemical parameters and chitin in seston size fractions, Wetlands Ecol. Manage., 19, 109-119, 2011.

Lipp, E. and Westrich, J.: More atmospheric dust from global desertification could lead to increases of harmful bacteria in oceans, seafood, Oceans and human health initiative, http:// oceansandhumanhealth.noaa.gov/multimedia/ohh-climate.html, 2011.

Longhurst, A.: Ecological Geography of the Sea, 2 Edn., Elsevier Academic Press, USA, 2006.

Mahmud, Z. H., Neogi, S. B., Kassu, A., Wada, T., Islam, M. S., Nair, G. B., and Ota, F.: Seaweeds as a reservoir for diverse Vibrio parahaemolyticus populations in Japan, Int. J. Food Microbiol., 118, 92-96, 2007.

Mahmud, Z. H., Neogi, S. B., Kassu, A., Mai Huong, B. T., Jahid, I. K., Islam, M. S., and Ota, F. Occurrence, seasonality and genetic diversity of Vibrio vulnificus in coastal seaweeds and water along the Kii Channel, Japan, FEMS Microbiol. Ecol., 64, 209-218, 2008.

Malmstrom, R. R., Cottrell, M. T., Elifantz, H., and Kirchman, D. L.: Biomass production and assimilation of dissolved organic matter by SAR11 bacteria in the Northwest Atlantic Ocean, Appl. Environ. Microbiol., 71, 2979-2986, 2005.

Mouriño-Pérez R. R., Worden, A. Z., and Azam, F. Growth of Vibrio cholerae $\mathrm{O} 1$ in red tide waters off California, Appl. Environ. Microbiol., 69, 6923-6931, 2003.

Neogi, S. B., Chowdhury, N., Asakura, M., Hinenoya, A., Haldar, S., Saidi, S. M., Kogure, K., Lara, R. J., and Yamasaki, S.: A highly sensitive and specific multiplex PCR assay for simultaneous detection of Vibrio cholerae, Vibrio parahaemolyticus and Vibrio vulnificus. Lett. Appl. Microbiol., 51, 293-300, 2010.

Ogawa, H, Amagai, Y., Koike, I., Kaiser, K., and Benner, R.: Production of refractory dissolved organic matter by bacteria, Science, 292, 917-920, 2001.

Oliver, J. D., Wear, J. E., Thomas, M. B., Warner, M., and Linder, K.: Production of extracellular enzymes and cytotoxicity by Vibrio vulnificus, Diagn. Microbiol. Infect. Dis., 5, 99-111, 1986.

Pernthaler, J. and Amann, R.: Fate of heterotrophic microbes in pelagic habitats: focus on populations, Microbiol. Mol. Biol. Rev., 69, 440-461, 2005.

Pohl, C. and Hennings, U.: The coupling of long-term trace metal trends to internal trace metal fluxes at the oxic-anoxic interface in the Gotland Basin; $\left(57^{\circ} 19,20 \mathrm{~N} ; 20^{\circ} 03,00 \mathrm{E}\right)$ Baltic Sea, J. Mar. Sys., 56, 207-225, 2005.

Pohl, C., Hennings, U., Croot, P., Daberkow, T., Budeus, G., and Rutgers v.d. Loeff, M.: Synoptic transects on the distribution of 
trace elements $(\mathrm{Hg}, \mathrm{Pb}, \mathrm{Cd}, \mathrm{Cu}, \mathrm{Ni}, \mathrm{Zn}, \mathrm{Co}, \mathrm{Mn}, \mathrm{Fe}, \mathrm{Al})$ in surface waters of the Northern- and Southern East-Atlantic, J. Mar. Syst., 84, 28-41, 2011.

Pomeroy, L. R. and Wiebe, W. J.: Temperature and substrates as interactive limiting factors for marine heterotrophic bacteria, Aquat. Microb. Ecol., 23, 187-204, 2001.

Porter, K. G. and Feig, Y. S.: The use of DAPI for identifying and counting aquatic microflora, Limnol. Oceanogr. 25, 943-948, 1980.

Redfield, A. C., Ketchum, B. H., and Richards, F. A.: The influence of organisms on the composition of seawater, in: The Sea, edited by Hill, M. N., Vol. 2, Wiley Interscience, New York, 26-79, 1963.

Reinthaler, T. and Herndl, G. J.: Seasonal dynamics of bacterial growth efficiencies in relation to phytoplankton in the southern North Sea, Aquat. Microb. Ecol., 39, 7-16, 2005.

Roszak, D. B. and Colwell, R. R.: Survival strategies of bacteria in the natural environment, Microbiol. Rev., 51, 365-379, 1987.

Schattenhofer, M., Fuchs, B. M., Amann, R., Zubkov, M. V., Tarran, G. A., and Pernthaler, J.: Latitudinal distribution of prokaryotic picoplankton populations in the Atlantic Ocean, Environ. Microbiol., 11, 2078-2093, 2009.

Skoog, A., Thomas, D., Lara, R., and Richter, K.: Methodological investigations on DOC determinations by HTCO method, Mar. Chem., 56, 39-44, 1997.

Sun, F., Chen, J., Zhong, L., Zhang, X. H., Wang, R., Guo, Q., and Dong, Y.: Characterization and virulence retention of viable but nonculturable Vibrio harveyi, FEMS Microbiol. Ecol. 64, 37-44, 2008.

Taniguchi, A. and Hamasaki, K.: Community structures of actively growing bacteria shift along a north-south transect in the western North Pacific, Environ. Microbiol., 10, 1007-1017, 2008.

Taylor, B. B., Torrecilla, E., Bernhardt, A., Taylor, M. H., Peeken, I., Röttgers, R., Piera, J., and Bracher, A.: Bio-optical provinces in the eastern Atlantic Ocean and their biogeographical relevance, Biogeosciences, 8, 3609-3629, doi:10.5194/bg-8-36092011, 2011.
Teira, E., Reinthaler, T., Pernthaler, A., Pernthaler, J., and Herndl, G. J.: Combining catalyzed reporter deposition-fluorescence in situ hybridization and microautoradiography to detect substrate utilization by bacteria and Archaea in the deep ocean, Appl. Environ. Microbiol., 70, 4411-4414, 2004.

Thompson, F. L., Iida, T., and Swings, J.: Biodiversity of vibrios, Microbiol. Mol. Biol. Rev., 68, 403-431, 2004.

Verado, D. J., Froelich, P. N., and McIntyre, A.: Determination of organic carbon and nitrogen in marine sediments using the Carlo Erba NA-1500 Analyzer, Deep-Sea Res., 37, 157-165, 1990.

Weinbauer, M. G., Christen, R., and Höfle, M. G.: The response of Vibrio- and Rhodobacter-related populations of the NW Mediterranean Sea to additions of dissolved organic matter, phages, or dilution, Microb. Ecol., 51, 336-344, 2006.

Wietz, M., Gram, L., Jørgensen, B., and Schramm, A.: Latitudinal patterns in the abundance of major marine bacterioplankton groups, Aquat. Microb. Ecol. 61, 179-189, 2010.

Wiebe, W. J., Sheldon, W. M., and Pomeroy, L. R. Evidence of an enhanced substrate requirement by marine mesophilic bacterial isolates at minimal growth temperatures, Microb. Ecol. 25, 151160, 1993.

Williams, P. J. le B.: Heterotrophic bacteria and the dynamics of dissolved organic material, In: Microbial Ecology of the Oceans, edited by: Kirchman, D. L., Wiley-Liss, New York, 153-200, 2000.

Wu, J., Sunda, W., Boyle, E. A., and Karl, D. M.: Phosphate depletion in the western North Atlantic Ocean, Science 289, 759-762, 2000.

Yildiz, F. H. and Visick, K. L.: Vibrio biofilms: so much the same yet so different, Trends Microbiol. 17, 109-118, 2009.

Zapata, M., Rodríguez, F., and Garrido, J. L. Separation of chlorophylls and carotenoids from marine phytoplankton: a new HPLC method using a reversed phase C-8 column and pyridinecontaining mobile phases, Mar. Ecol. Prog. Ser. 195, 29-45, 2000 . 